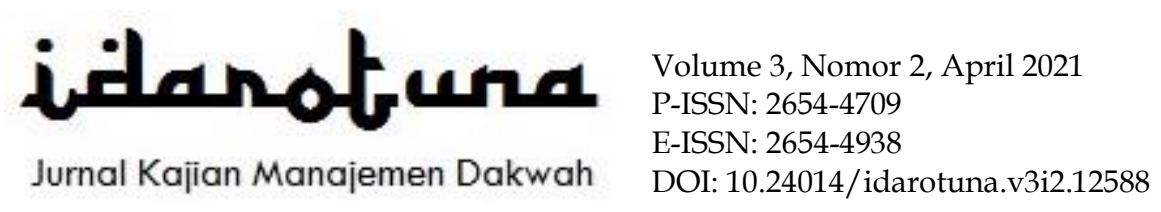

\title{
Adaptasi Gerakan Dakwah di Tengah Pendemi Covid-19: Studi Kasus Teras Dakwah
}

\author{
Taufik Habibi ${ }^{1}$ \\ ${ }^{1}$ Pascasarjana UIN Sunan Kalijaga Yogyakarta \\ Email: habiby.alhabsy11@gmail.com
}

\begin{abstract}
This article analyzes the da'wah movement during the pandemic in breaking the chain of the spread of the Covid-19 virus in Yogyakarta. This study used a qualitative approach using interview methods, observation of the Teras Dakwah dakwah institute. This article shows that Covid-19 has produced creative da'wah programs, such as the Super Booster, \#Tetapdirumahaja, da'wah comics, Geber Pangan. With Covid-19, Teras Dakwah is increasingly challenged by social distancing to produce creative content. For example the charity program, Teras Dakwah formed a Geber Pangan team to deal with the impact of Covid-19 and conducted a campaign on the importance of implementing health protocols. In the end, the Teras Dakwah movement produced new, creative and innovative da'wah programs.
\end{abstract}

Keywords: Teras Dakwah; Covid-19; Da'wah program

Abstrak: Artikel ini menganalisis gerakan dakwah di masa pandemi dalam memutus mata rantai penyebaran virus Covid-19 di Yogyakarta. Penelitian ini dengan pendekatan kualitatif menggunakan metode wawancara, observasi terhadap lembaga dakwah Teras Dakwah. Artikel ini menunjukkan bahwa Covid-19 telah menghasilkan program-program dakwah kreatif, seperti Super Booster, \#Tetapdirumahaja, komik dakwah, Geber Pangan. Dengan Covid-19 justru Teras Dakwah semakin tertantang dengan adanya pembatasan sosial (social distancing) untuk memproduksi konten-konten kreatif. Misalnya program karitas, Teras Dakwah membentuk gugus tim Geber Pangan untuk menangani dampak Covid-19 dan melakukan kampanye tentang pentingnya menerapkan protokol kesehatan. Pada akhirnya gerakan Teras Dakwah menghasilkan program-program baru, dakwah yang kreatif dan inovatif.

Kata kunci: Teras Dakwah, Covid-19, Program Dakwah

\section{Pendahuluan}

Kasus SARS-CoV-2 atau Covid-19 di Indonesia saat ini sudah mencapai lebih dari 1 juta jiwa (Sari, n.d.). Lonjakan kasus Covid-19 yang begitu tinggi ini membuat pemerintah kembali menaikkan kasus Covid-19 menjadi Pembatasan Sosial ke Pembatasan Sosial Berskala Besar (PSBB) pasti memerlukan agama. Di sejumlah kota sudah mulai menerapkan pembatasan sosial. Kota Jogja salah satu di antara yang kembali menerapkan PSBB. Angka yang mencapai 1 juta lebih ini menunjukkan bahwa negara Indonesia diklasterisasikan sebagai negara yang terburuk menangani Covid-19 di Asia Tenggara. Indonesia menempatkan berada di urutan 4 di negara Asia Tenggara dan nomor 19 dunia, yang memiliki jumlah kasus Covid-19 tertinggi (Nurdiana, n.d.). Lamban dalam menangani Covid-19 menyebabkan angka Covid-19 di Indonesia semakin terus naik. Kebijakan pemerintah dianggap kurang efektif dalam menekan laju Covid-19 di 
berbagai provinsi terutama kota-kota besar Indonesia seperti Jakarta, Surabaya, Semarang, Medan dan Balik Papan. Rumah sakit pasien semakin terus bertambah, tenaga medis semakin berguguran, fasilitas tempat penampungan pasien semakin penuh. Kasus Covid-19 yang begitu tinggi.

Studi-studi sebelumnya membahas tentang peranan penting agama dalam perubahan sosial masyarakat dilakukan oleh Amran. Dalam studinya menyimpulkan bahwa kondisi masyarakat yang selalu mengalami perubahan sosial baik secara lambat ataupun cepat. Karena pada dasarnya masayarakat yang bersifat dinamis tidak bisa menolak adanya perubahan (Amran, 2015). Studi lain juga dilakukan oleh Buana tentang analisis perilaku masyarakat Indonesia dalam menghadapi pandemi virus Corona (Covid-19) dan kiat menjaga kesejahteraan jiwa. Dalam penelitiannya menyatakan bahwa masyarakat Indonesia masih banyak yang mengabaikan arahan kebijakan pemerintah terkait wabah Covid-19. Perilaku yang salah tidak mematuhi arahan serta kebijakan pemerintah (Buana, 2020).

Studi yang dilakukan oleh Ahmad tentang Konsepsi Fikih Dakwah Jama'ah Tabligh Pada Masa Pandemi Covid-19: Telaah Gerakan Dakwah Jama'ah Tabligh Gorontalo menyimpulkan bahwa pemahaman Jamaah Tabligh dalam berdakwah tidak sejalan berdasarkan hukum fikih dan hukum Islam, yang tidak selalu berdasarkan pertimbangan agama secara sendiri. Namun, fikih dan hukum Islam juga perlu untuk berdialog dengan realitas sosial agar sejalan dengan nilai-nilai kemanusiaan (Zaenuri, 2020). Studi lain juga dilakukan oleh Maliki. Dalam studinya membahas tentang Covid-19, Agama, dan Sains. Studinya menunjukkan bahwa praktik ibadah masyarakat Gorontalo selama pendemik tidak menerapkan protokol kesehatan, seperti menjaga jarak, menghindari kerumunan, tidak memakai masker, dan tidak mencuci tangan. Masyarakat Gorontalo tersebut abai terhadap penerapan protokol kesehatan, tidak patuh terhadap pemerintah dan lembaga kesehatan. Menurut mereka hal ini karena musibah yang ada di bumi ini adalah datang dari Allah SWT. Manusia tidak bisa menghindarinya. Jika seorang terkena Covid-19 maka ini merupakan ketentuan takdir Allah. Datang dan perginya Covid-19 ialah takdir yang sudah ditentukan oleh Allah. Dalam konteks seperti ini agama dijadikan sebagai alat, identitas dan aliran pemikiran (mazhab) yang ekstrim (kaku). Agama tidak membuka diri dengan sains dan kesehatan. Agama tidak bisa menyesuaikan dengan perubahan yang terjadi di sekelilingnya (M., 2020).

Studi senada juga dilakukan oleh M. Alkaf tentang Agama, Sains, dan Covid-19: Perspektif Sosial-Agama dalam studinya menyimpulkan bahwa hubungan agama dan sains memiliki dua varian yaitu oposisi biner dan upaya dialog. Dimana berdasarkan sejarah, agama dan sains selalu bertentangan, sehingga berdampak terhadap dunia Muslim yang melihat keduanya di masa lalu, dengan demikian beberapa gerakan berupaya untuk mendialogkan keduanya seperti islamisasi ilmu pengetahuan maupun integrasi dan interkoneksi ilmu pengetahuan (Alkaf., 2020). Studi lain juga dilakukan oleh Zainab tentang Integrasi Sains dan Agama: Meruntuhkan Arogansi di Masa Pandemi Covid-19, menyimpulkan bahwa dengan tataran pemikiran diharapkan agamawan dan saintisme mampu memandang wabah Covid-19 dengan paradigma integralistik, sehingga arogansi keduanya diminimalisasi agar masyarakat 
dunia mampu menyelesaikan masalah yang terjadi dengan hati dan pikiran yang jernih (Toresano, 2020).

Studi-studi di atas, mulai dari Amran, Buana, Ahmad, Malik, sampai Zainab menunjukkan berbagai artikulasi praktek keagamaan masyarakat Indonesia di tengah pandemi. Di samping pemerintah yang kurang maksimal dalam melakukan kebijakan PSBB pada awalawal pendemik, pemahaman yang tidak merata tentang pentingnya untuk merapkan protokol kesehatan juga menjadi salah satu penyebab meningkatnya kasus Covid-19 di Indonesia. Masyarakat yang kurang patuh dengan protokol, susah untuk menjaga jarak, pakai masker penyebab angka kasus Covid-19 semakin bertambah. Selain itu, masih banyak aktor keagamaan yang abai terhadap social distancing juga menjadi salah satu kasus Covid-19 naik. Masjid-masjid masih banyak tidak menerapkan social distancing, menyelenggarakan kajian secara kerumunan dan melaksanakan solat jamaah tanpa pembatasan sosial.

Namun, walaupun masih banyak aktor keagamaan yang tidak menerapkan protokol kesehatan, Teras Dakwah sebagai salah satu contoh gerakan dakwah yang menerapkan protokol kesehatan di Kota Yogyakarta. Dengan menerapkan protokol kesehatan Teras Dakwah patuh mengikuti himbauan pemerintah, tenaga medis dan juga badan kesehatan dunia. Teras Dakwah ingin menjadi pelopor gerakan dakwah anak muda penegakan protokol kesehatan. Misalnya uraian ini dilihat berdasarkan hasil kajian online yang disampaikan oleh pengurus Teras Dakwah Mas Awan Abdullah, Sp. J, dengan tema Perkuat Imun dengan Iman.

Teras Dakwah ialah salah satu lembaga gerakan dakwah sekaligus otoritas yang menampilkan identitas budaya populer dalam sosial keagamaan komunitas anak muda Muslim Kota Yogjakarta yang mengalami penyesuian dakwah akibat Covid-19 (Triantoro, 2018; Triantoro, Saputra dan Wahyuni, 2019). Pengajian yang biasanya diselenggarakan secara offline kini harus dilakukan dengan cara online. Akibatnya jamaah tidak bisa mengikuti kajian seperti biasanya. Mereka mengikuti kajian secara online. Jamaah menikmati pesan-pesan keagamaan melalui media online seperti Twitter, Youtube, Instagram dan lainya. Melalui media sosial jamaah dapat menikmati pengajian Islam yang disampaikan oleh ustaz-ustaz Teras Dakwah. Selain menyimak kajian mereka juga bisa melihat program-prorgam pilihan Teras Dakwah lainnya seperti Podcast, Qoutes dakwah, One Minutes Booster, Web Series, Super Booster dan awan cinta. Misalnya uraian ini dilihat berdasarkan hasil kajian online yang disampaikan oleh pengurus Teras Dakwah dengan tema liburan kok diruamah aja bersama Alredo Di Stefano (Muslim Traveller 25 Negara). Program tersebut dibuat di masa pendemi, dengan tujuan untuk meningkatkan antusias jamaah di saat masa pendemi di saat psikologis jamaah sedang mengalami keterpurukan.

Memahami keterpurukan psikologis jamaah di masa pendemi ini membuat Teras Dakwah antusias menghadirkan program-program baru, dakwah menarik yang dapat dinikmati oleh semua orang di rumah tanpa harus khwatir terkena virus Covid-19. Sambil kumpul keluarga jamaah bisa menikmati program-prgram pilihan Teras Dakwah melalui media sosialnya. Program Podcast, Qoutes dakwah, One Minutes Booster, Web Series, Super Booster dan awan cinta didesain untuk mengobati kebosanan masyarakat yang harus tetap di rumah. Di setiap 
konten dakwah disusupi pesan-pesan humor agar jamaah merasa terhibur. Upaya ini sebagai bentuk meningkatkan semangat kembali jamah. Dengan program tersebut mereka akan terasa semangat kembali, berfikir positif dan menumbuhkan kecintaanya dengan Teras Dakwah.

\section{Metode}

Untuk memperkuat argumen di atas, bagaimana gerakan dakwah Teras Dakwah mengalami perubahan yang beriorentasi pada agama dan sains atas pandemi Covid-19 yang terjadi, penulis mengambil studi kasus Teras Dakwah. Teras Dakwah sebagai studi kasus penulis untuk menunjukkan bagaimana gerakan dakwah populer mengalami perubahan terhadap pandemi yang terjadi. Untuk menjawab studi ini penulis melakukan studi etnografi di lembaga Teras Dakwah dengan mengikuti kajian dakwah offline, dan kajian online seperti Podcast, Qoutes dakwah, one minutes booster, web series, super booster dan awan cinta. Kemudian komunikasi langsung dengan pengurus Teras Dakwah, serta mengikuti perkembangan media sosial Teras Dakwah secara online. Dari data yang didapat selama penelitian, penulis uraikan, diskusikan dengan topik bahasan yang relevan dengan penelitian ini.

Artikel ini penulis diskusikan ke dalam beberapa bahasan, di antaranya sebagai berikut: (1) Teras Dakwah Dan Penyesuian Pendemi Covid-19 Terhadap Protokol Kesehatan (2) Konteks Penyesuaian Program Keagaman Teras Dakwah di Masa Pendemi (3) Ragam Komentar Netizen Online-Offline di Masa Pendemi (4) Kemampuan Teras Dakwah dalam Menayangkan Program Dakwah Tebaik (5) Teras Dakwah, Covid-19 dan Gagasan Karitasnya (6) Kesimpulan.

\section{Hasil dan Pembahasan}

\section{Teras Dakwah dan Penyesuaian Terhadap Protokol Kesehatan Covid-19}

Lembaga Teras Dakwah telah memposisikan sikap yang tepat bagi jamahnya untuk selalu menghimbau mematuhi protokol kesehatan. Aktivitas pengajian keislamanya dibatasi dengan mengurangi jumlah jamaah. Jika jamaah ingin mengikuti pengajian ia harus mengikuti prosedur yang sudah ditetapkan oleh Teras Dakwah. Jumlah yang mengikuti pengajian offline dibatasi tidak lebih dari 30\% dari kapasitas normal. Pembatasan jumlah ini dilakukan untuk mencegah penularan Covid-19. Walaupun tetap masih ada pihak aktor keagamaan yang masih tetap menghiraukan tidak mematuhi protokol kesehatan, namun sebaliknya Teras Dakwah mencontohkan sebagai gerakan dakwah yang mematuhi protokol kesehatan.

Teras Dakwah ingin menjadi contoh bagi gerakan dakwah lain maupun masjid-masjid tempat untuk melangsungkan rutinitas ibadah-ibadah mahdhah yang menjalankan protokol kesehatan. (D, 2012) Di masa pendemi seperti ini edukasi melalui institusi agama sangat penting untuk meningkatkan kesadaran umat beragama bahwa menerapkan protokol kesehatan sangat penting. Protokol kesehatan tidak hanya untuk melindungi diri dari bahaya virus, melainkan juga melindungi orang lain agar tidak terkena Covid-19.

Dimulai dari institusi agama taat mematuhi protokol kesehatan angka kenaikan kasus Covid-19 dapat ditekan. Melalui cara ini Teras Dakwah ingin menunjukan bahwa agama, 
kesehatan dan sains dapat berjalan bersama. Sehingga perpaduan secara normatif-teoritis akan saling terkait secara langsung yang meliputi ontologis, epistimologis dan aksiologis terhadap faktor utama yang harus dilakukan (Zaprulkhan, 2015). Pentingnya menerapkan protokol kesehatan bagian dari agama. Sains dan agama ialah bagian rumpun keilmuan yang saling terkait satu sama lain. Integrasi antar agama, sains dan kesehatan ialah formula keilmuan yang sedang dibutuhkan bagi institusi agama dalam menangani pendemi seperti saat ini. Kolaborasi antar keilmuan sangat dibutuhkan untuk mengatasi krisis kemusiaan, pangan, ekonomi, bisnis dan pendidikan. Menyatukan antara ketiga hal tidak hanya tugas pemerintah melainkan juga tugas bersama. Semua khalayak penting melakukan social ditancing, menjaga jarah dan selalu memakai masker.

Walau terasa dalam masa sulit seperti ini, di saat jamaah sedang menginginkan kajian langsung, Teras Dakwah tetap belum membuka kajian secara biasa. Hal ini dilakukan untuk menekan kenaikan kasus Covid-19. Keselamatan jamaah menjadi prioritas Teras Dakwah. Untuk itu Teras Dakwah mengalami pergerseran dakwah yang beriorentasi pada agama pasar secara offline ke online dan mulai banyak membuat program baru untuk jamaah (Saputra, 2020). Berbagai otoritas kesehatan di seluruh dunia, mulai dari pusat pengendalian dan pencegahan wabah hingga badan kesehatan dunia mengingatkan soal pentingnya tinggal di rumah selama penyebaran virus Covid-19 masih terjadi. Sejumlah kalangan aktor agama juga memberikan respons dan fatwa terhadap fenomena Covid-19 walau masih banyak yang tidak menghiraukan protokol kesehatan. Tokoh agama, misalnya, telah menetapkan PSBB untuk memutus penularan Covid-19 di Indonesia.

Upaya ini tidak lain adalah tindakan yang diambil berdasarkan riset dan fakta sains. Beberapa kebijakan di antaranya adalah "merumahkan" para pelajar dan mahasiswa untuk belajar di rumah, menunda kegiatan-kegiatan yang melibatkan banyak orang, serta hal-hal lain yang sifatnya mengundang kerumunan massa. Begitu pula langkah yang diambil oleh MUI (Majelis Ulama Indonesia) dengan mengeluarkan fatwa nomor 14 tahun 2020 tentang penyelenggaraan ibadah dalam situasi terjadi wabah Covid-19 (Sholeh, n.d.). Kurang lebih isi dari fatwa ini adalah instruksi peniadaan kegiatan keagamaan di masjid seperti sholat jum'at.

Dengan menerapakan protokol kesehatan Teras Dakwah menguraikan bertapa pentingnya bagi semua kalangan untuk sama-sama menerapkan protokol kesehatan, menjaga jarak, selalu pakai masker ketika keluar rumah, menghindari kerumunan dan selalu mencuci tangan jika habis keluar rumah. Jika semua menerapkan protokol kesehatan maka angka Covid-19 yang tinggi akan semakin turun. Pendemi akan segera berakhir, dan pelaksanaan kajian secara offline kembali dapat dilaksanakan.

\section{Konteks Penyesuaian Program Keagamaan Teras Dakwah di Masa Pendemi}

Semenjak Covid-19 melada dunia berbagai kajian progam keagamaan ibadah kini banyak yang menyelengarakan kajian secara online. Tidak hanya protestan, Nasrani, Hindu dan Buddha, Islam juga yang melakukan banyak aktivitas keagamaan harus mengubah orientasi ibadah dari offline ke online. Perubahan ini dilakukan untuk mencegah penularan Covid-19. Pelaksanaan 
ibadah menjadi tempat yang rentan terhadap penyebaran virus Covid-19. Salah satu di antara yang melakukan penyesuaian program dari offline ke online ialah Teras Dakwah. Teras Dakwah mengubah pengajianya ke online. Lochhend mengatakan bahwa kelompok agama online akan membentuk komunitas secara independen dari berbagai prangkat yang mereka pilih untuk berkomunikasi secara digital dengan memanfaatkan beberapa platfrom sebagai ruang percakapan keagamaan (Campbell, 2012). Dalam hal ini, hanya beberapa jamaah yang mengikuti pengajian setelah melakukan rangkaian seleksi. Yang biasanya pengajian Teras Dakwah banyak mulanya menapung ratusan jamaah kini hanya dapat dihitung dengan jari. Yang bisanya sebelum kajian dimulai pelataran halaman Teras Dakwah penuh dengan jamaah. Mereka duduk di depan bangunan Teras Dakwah, jongkok di pelataran jaman, berdiri di pinggir pintu masuk Teras Dakwah berbincang-bincang dengan teman-temanya saat sebelum pengajian dimulai kini suasana seperti tidak ditemukan.

Dari pebatasan social distancing Teras Dakwah program yang disiarkan langsung oleh Teras Dakwah ialah Ngaji Teras, Ngaji Qohwah, kemudian Podcast, Qoutes Dakwah, One Minutes Booster, Web Series, Review Asik dan konten-konten dakwah kreatif lainnya. Programprogram ini disiarkan langung melaui media online akun media sosial Teras Dakwah seperti Facebook, Instagram dan Youtube. Media tersebut menawarkan progam pengajian. Ngaji Teras yang dilakukan secara offline pada hari rabu di pindah ke online. Dengan nuansa yang berbeda, agar jamaah antusias mengikuti pengajian Teras Dakwah, konsep pengajian di baat dengan cara berbeda. Pertama, dimulai dari desain konsep panggung.

Konsep desain panggung menggunakan gerdu model Lombok. Gerdu ini berukuran 3x4 meter, seperti dalam acara gerdu program merakyat di TV, program ini dinilai akan memberikan nuansa berbeda. konsep duduk di gerdu membuat suasana merakyat. Di tambah dengan logo Teras Dawah yang berawarna kuning keemasan dengan pantulan sinar kuning membuat background makin kekinian. Nyantai dalam membawakan suasana kajian dengan model nongkrong cerita membuat porgam ini banyak dsukai oleh jamaah. Harls Evan R. Siahaan pernah mengatakan bahwa era digital membutuhkan sebuah bentuk pelayanan yang mampu mengaktualisasikan karunia untuk melayani yang sesuai dengan prinsip digitalisasi (Siahaan, 2017).

Kedua, tema kajian dibuat dengan cara menarik, bobot kajian yang ringan, seperti tips menjaga diri dari Covid-19, mempertebal imun saat pendemi dan cinta-cinta mengudang jamaah menyimak kajian. Bahasa gaul dan bagian dari kampanye dakwah Teras Dakwah yang lentur, sejuk dan humor (lucu). menghadirkan kesan seperti ini sangat dibutuhkan oleh jamaah disaat mereka sedang mengalami masa suntuk. Memerlukan hiburan, stres, gelisah. Ketika mereka mendengarkan kajian dakwah yang isinya ringan tidak makin menambah beban jamaah maka akan menolong psikologis mereka. Kemudian program ini didukung dengan alat-alat teknologi modern canggih. Mulai dari camera, tripot, sound system, jaringan internet dan lainnya. Kecanggihan alat tersebut untuk mendukung program acara di masa pendemi. Alat yang canggih dan progam dakwah banyak untuk meningatkan keantusiasan jamaah. Program ini dilakukan 
bentuk penyesuaian dampak Covid-19. Program tersebut di antaranya Ngaji Teras dan Ngaji Qohwah. Program ini sangat disukai jamaah. Program ini menjadi favorite kajian jamaah.

Selain progam Ngaji Teras dan Ngaji Qohwah juga terdapat program lain seperti Ngaji Multimedia, Ngaji Ta'aruf. Ngaji program ini untuk mengasah kemapuan media jamaah. Ngaji Multemedia untuk meningkatkan pengetahuan jamaah tentang media. di sini mereka akan belajar tentang mengasah skill fotografer, vidiografer, editing, copywriting, copyeditor, desainer dan web developer. Skill yang penulis sebutkan ini diajarkan di program Ngaji Multimedia. Kemampuan jamaah di program ini akan diasah, bila mereka memiliki kualifikasi dengan baik mereka akan direkrut dijadikan sebagai tim kreatif dari media Teras Dakwah. Berawal dari program ini Teras Dakwah bisa menarik perhatian jamaah yang memiliki kecenderungan hobi dengan multimedia. Program ini juga sebagai bentuk mem-follow-up anak-anak muda muslim yang memiliki kemahiran dalam media. Mereka yang punya kemampuan skill yang baik akan diajak bergabung dengan Teras Dakwah.

Selain untuk mengasah bakat, program media juga bisa mengisi jamaah, saat mereka suntuk mereka bisa luangkan aktivitasnya untuk belajar media. Belajar sesuai yang baru apalagi menyangkut tetang keterampilan dalam bermedia akan mendapat respons baik oleh jamaah. Hal ini sesuai dengan komentar jamaah yang ada di bio komen Intagram Teras Dakwah dalam sebuah postingan yang berjudul "We Want You". Dalam ungahan tersebut Teras Dakwah mengajak jamaah untuk bergabung dengan tim kreatif media Teras Dakwah. Agar konten Teras Dakwah lebih bagus lagi jamaah yang memiliki potensi media diajak bergabung untuk membuat produk dakwah yang lebih menarik. Sehingga kualitas produk Teras Dakwah semakin bagus banyak diminati oleh jamaah luas. Like dan comment jamaah bagi yang ingin bergabung maupun hanya mengapresiasi pencapaian prestasi Teras Dakwah mereka sama-sama memiliki Teras Dakwah. Teras Dakwah menjadi bagian dari diri mereka.

Kemudian kajian selanjutnya yang banyak disukai anak muda ialah Ngaji Taruf, bersama ustaz Awan Abdullah (Dakwah, n.d.-b). Ngaji ini digagas oleh tim Teras Dakwah yang memahami tentang asmara anak muda. asmara ialah bagian dari kehidupan rutinitas anak muda yang tidak bisa mereka tinggalkan. Taruf termasuk kajian yang banyak dilihat jamaah Teras Dakwah. Program ini menghadirkan tema-tema ringan, sepeti cara memilih jodoh yang baik dalam Islam, mengobati kegalauan, bersikap komitmen dengan pasangan, menumbuhkan rasa cinta, menghindari godaaan rumah tangga dan lain sebagainya (Triantoro, 2018).

Tema percintaan seperti ini sangat disenangi jamaah, terutama mereka yang belum menikah sedang mencari pasangan. Pembahasan percintaan yang sedang bergejolak di usia muda akan membuat jamaah merasa penting untuk mengikuti pengajian Ngaji Ta'aruf ini. Dengan kemasan penyampaian menarik semakin membuat jamaah susah beranjak dari kajian. Ini menunjukkan bahwa media sosial memiliki pengaruh besar terhadap perkembangannya programprogram gerakan dakwah. Media sosial membuat program dakwah semakin terus maju. Media sosial membawa jamaah pada ruang yang sakret. Media sosial membawa perubahan pada kepribadian Muslim menjadi muslim yang baik dalam perspektif Islam. dan salah satu prioritas 
gerakan dakwah ialah mengajak setiap orang kembali ke jalan yang di kehendaki oleh ajaran agama Islam melalui media dakwah (Mughni, 2011).

Selanjutnya yang tidak kalah dengan program lain ialah video posternya. Video poster Teras Dakwah dikemas dengan cara menarik. Selain memiliki konten dakwah yang mengajak ke hal kebaikan juga memiliki sisi humor (lucu). Tidak seperti video Islam lain yang terlihat kaku, video poster Teras Dakwah banyak menyimpan pesan-pesan humor (lucu), sehingga jamah tidak merasa seperti diceramahi, melainkan dihibur. Pesan yang disampaikan mengulas seputar kehidupan sehari-hari. Bahasanya mudah dipahami dan diterapkan dalam kehidupan sehari-hari. Dakwah dengan cara humor (lucu) seperti ini mudah bagi jamah untuk menyerap ilmu agama. Bagi anak-anak muda perkotaan dakwah dengan cara serius tidak akan membuat mereka sukai. Mereka akan memilih agama sesuai dengan kehidupan mereka. Mereka akan mencari agama berdasarkan dengan kebutuhannya. Oleh karena itu, aktor lembaga dakwah memposisikan agama sesuai dengan keinginan pasar. Lembaga dakwah harus bisa memenuhi sisi agama berdasarkan dengan keinginan pasar.

Selain dalam bentuk video juga terdapat media poster yang tak kalah bagusnya juga dengan video poster. Misalnya sepeti Quotes dakwah, Qoues Nasehat, Qotes Ustaz, tema kajian, TD MAGZ, TD Story, TD Post dan TD Heroik. Produk tersebut ialah media poster Teras Dakwah yang dikemas dengan cara menarik, mulai dari pemilihan background, kalimat, tulisan, warna iluslator sampai desain. Kemasan dakwah media poster yang sangat menarik, kekinian membuat jamaah semakin antusias melihat produk Teras Dakwah. Selengkapnya pembaca bisa melihat melalui media sosial Teras Dakwah seperti Instagram \#terasdakwah. Beragam program pilihan yang dikemas dengan cara kekinian akan mengurai stres jamaah. Pada saat tekanan psikologis menunjak disebabkan oleh Covid-19 jamaah dapat melihat tayangan media poster Teras Dakwah mulai Quotes dakwah, Qoutes Nasehat, Quotes Ustaz, tema kajian, TD MAGZ, TD Story, TD Post sampai TD Heroik. Dengan demikian program online Teras Dakwah yang dibuat dengan bagus yang menarik adalah bentuk membuktikan Teras Dakwah di masa sulit pendemi ini tetap bisa menghasilkan konten dakwah yang bagus.

\section{Ragam Komentar Netizen Online-Offline di Masa Pendemi}

Castell mengatakan bahwa ciri khas dari informasionalisme bersifat kompleks, integritas, dan cepat (Castell, 2000). Di masa pendemi program agama difokuskan ke online. Untuk menghindari kerumunan, jamaah diarahkan menikmati tayangan dakwah melalui media sosial. Jika dilihat dari tayangan dakwah online yang mencolok ialah komentar netizen. Para netizen teras dakwah dapat dikategorikan ke dalam 2 hal. Selain itu juga jamaah pengajian onlineoffline. Komentar tersebut diambil melalui video poster, video full kajian, Qoutes Ustaz, TD Nasehat, dan testinomi-testimoni jamaah-netizen yang di-share melalui media sosial Teras Dakwah.

Konten dakwah yang diproduksi oleh tim TD Media Teras Dakwah menuai ragam komentar yang menarik, bahkan banyak jamaah yang menilai video-video kreatif Teras Dakwah dinilai lucu dan humor. Hal ini berdasarkan kolom komentar yang penulis temukan di media 
sosial Teras Dakwah. Komentar tersebut merepresentasikan dari berbagai kalangan anak muda baik secara lokal (khusus Yogyakarta) maupun trans-lokal (nasional) yang terdelokalisasi menembus batas-batas wilayah, identitas, dan sosial budaya. Selengkapnya sebagai berikut:

Para netizen yang bergabung ke media sosial Teras Dakwah, seperti Instagram, mereka banyak yang mengapresasi hasil produk video dakwah Teras Dakwah. Video yang diunggah ke akun media sosialnya dianggap inspiratif, kreatif dan memiliki karakteristik pesan dakwah yang berbeda dari video dakwah lainnya. Jamaah netizen Teras Dakwah aktif memantengi media sosial Teras Dakwah yang menginspirasi, menghibur dan mendidik. Penulis menilai, pujian ini dapat dilihat dari dua kecenderungan, yaitu like and comment. Satu kali posting vidio, seperti one minutes booster, Teras Dakwah mendapatkan puluhan ribu like oleh follower-nya. Penulis mengamati dalam sehari pengikut Teras Dakwah yang me-like unggahan video Teras Dakwah mencapai puluhan ribuan like-an. Representasi yang cukup besar ini menunjukan bahwa apresiasi yang luar biasa ditujukan oleh para jamaah online Teras Dakwah. Menurut penulis, yang menjadi pertimbangan jamaah banyak me-like video one minutes booster Teras Dakwah sampai puluhan ribu dalam sehari, bahkan ratusan ribu, tersebut adalah:

Pertama, output dari kualitas gambar yang digarap sangat apik (bagus). Kualitas gambar terang, jelas, tidak pecah, resolusi gambar jernih. Jika dilihat dari hasil garapan video gambar tersebut seperti dikerjakan oleh kalangan orang profesional. Hasil video yang diproduksi mantap, ciamis. Kedua, sound mixing-nya yang baik. Suara yang dihasilkan sangat sangat jernih, jelas, banyak menggunakan soundtrack. Ketiga, acting-nya yang natural. Cerita yang diperankan oleh para pemain bintang aktornya terkesan natural. Alur ceritanya ngalir, mencerminkan realitas kehidupan sosial anak muda, tidak banyak menampilkan plot twist gila-gilaan, dan tidak perlu adegan mendayu-dayu. Pesan moral yang ditampilkan dalam video tersebut sangat mengena, menangkap sisi realitas sosial kehidupan sehari-hari anak muda. Islam yang ditampilkan dalam video tersebut lebih akrab dengan tradisi seputar kehidupan anak muda, antara Islam dan modernitas.

Selanjutnya Keempat, video One Minute Booster tersebut dibuat dengan kemasan yang renyah, trendi, dan kreatif. Jalan cerita yang disuguhkan ke netizen sangat asyik, dan inspiratif tanpa mengurangi pesan moral nilai Islam. Kelima, yang tidak kalah dari keempat poin tersebut ialah video One Minutes Booster Teras Dakwah tersebut dikemas dengan humor-komedi yang membawa suasana penonton makin asyik. Ini dapat dilihat dari sinopsis alur cerita yang disuguhkan dalam video yang berjudul "Social Distancing" (Dakwah, n.d.-a). Lihat dalam gambar 1. Video ini telah memiliki 4583 tayangan dan beragam like. Dari video Social Distancing tersebut, penonton banyak yang terhibur dengan aksi kedua ketiga anak muda tersebut, terutama yang memerankan sebagai bodyguard. Di saat pak Jubir mentri kesehatan sedang menginformasikan perkembangan pendemi Covid-19 tersebut si bodyguard usil. Yang memakai baju kuning tidak sama ubahnya seperti bodyguard tersebut. Perannya membuat penonton merasa terhibur. Mereka pendamping jubir Covid-19 ala Mentri TD saat menyampaikan perkembangan Covid-19 dan penyambutan bulan Suci Ramadan. 
Gambar 1. Video kreatif sosial distancing teras dakwah

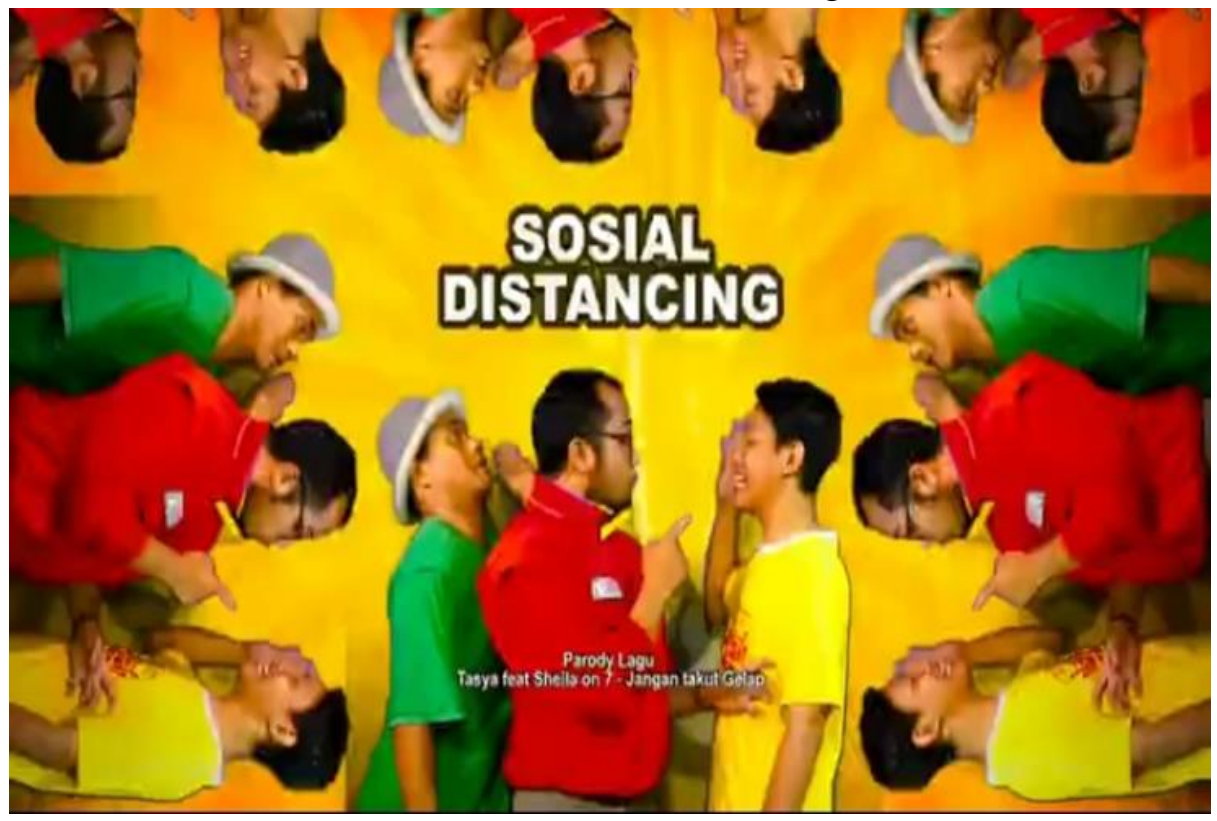

Para netizen yang berkomentar di kolom unggahan video one minutes booster juga tidak kalah antusiasnya dengan like dari netizen yang menyukai video Teras Dakwah. Tangan netizen gatal berkomentar di kolom Instagram Teras Dakwah karena di sebabkan oleh ceritanya yang menarik, lucu, humoris, kreatif, edukatif, dan yang utama adalah editing videonya yang berkualitas. Reolusi gambar, pencahayaan, iluslator dan kreator gambar diracik dengan hasil yang pas membuat netizen menyukai video Teras Dakwah.

Keantusiasan netizen dalam mengapresiasi video kratif Teras Dakwah dapat di lihat pada gambar 2. Berdasarkan gambar 2 tersebut netizen tidak bisa menahan rasa gatal jarinya di sebabkan adegan ceritanya yang lucu, humor, kreatif, menghibur, seperti yang terlihat dalam gambar 2 tersebut. Gambar tersebut menunjukan bahwa meningkatnya popularitas Teras Dakwah di antaranya di sebabkan oleh produk dakwah garapan video one minute booster Teras Dakwah yang kreatif, lucu dan humor, sehingga membuat netizen suka, tidak bisa menahan jarinya untuk komen. Teras Dakwah menghasilkan karya-karya kreatif, tidak hanya menghadirkan dakwah, melainkan juga humor, hiburan, dan edukasi, yang menghadirkan konten yang natural, tidak banyak plot swets, namun menyentuh, membuat para netizen gagal mengurungkan tangannya tidak berkomentar seperti yang terlihat dalam gambar 2 di bawah ini. 
Gambar 2. Komentar netizen dalam video poster Gagal Move One
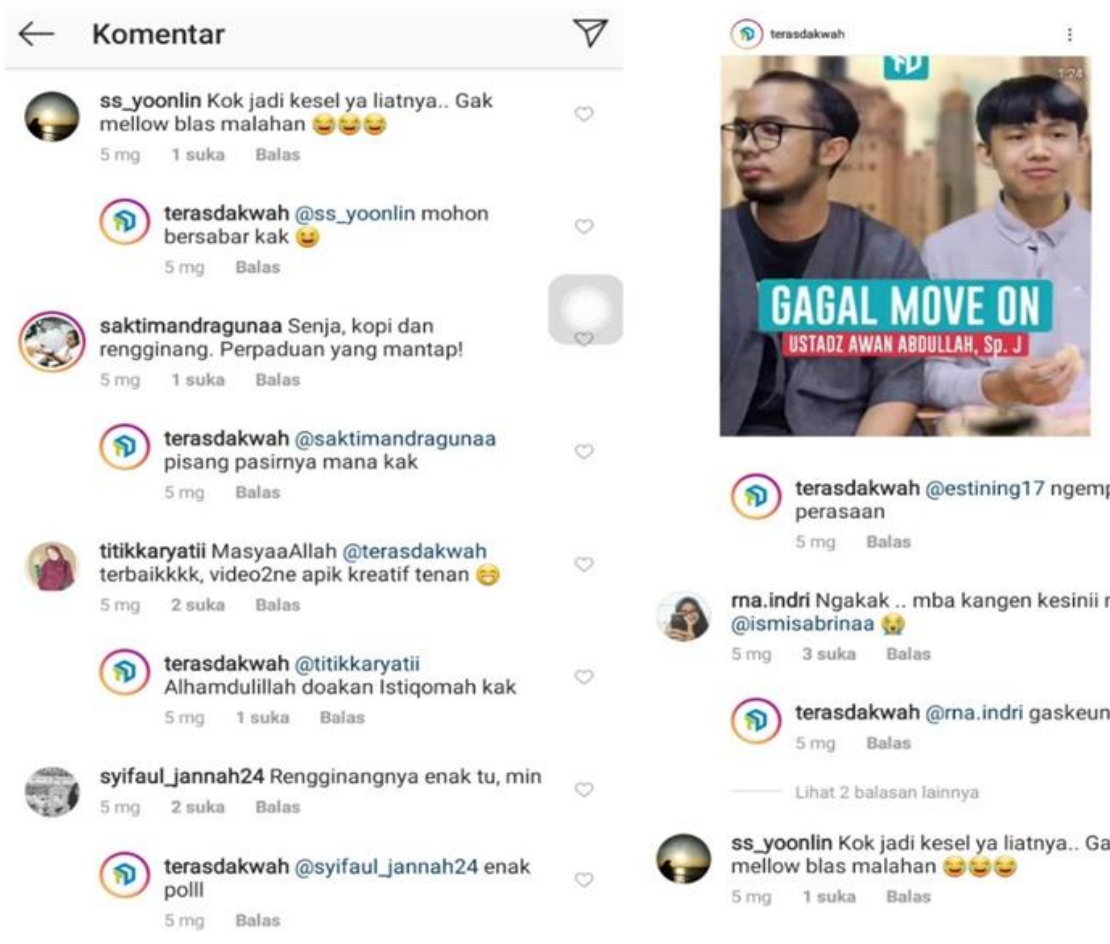

(D) terasdakwah @estining17 ngempet $5 \mathrm{mg}$ Balas 27 @ismisabrinaa @.. mba kangen kesinii mbaa $5 \mathrm{mg} 3$ suka Balas

(ㄱ) terasdakwah @rna.indri gaskeun kak Lihat 2 balasan lainnya

ss_yoonlin Kok jadi kesel ya liatnya.. Gak mellow blas malahan 90 $5 \mathrm{mg} 1$ suka Balas

\section{Jamaah Pengajian Online-Offline}

Kedua jamaah online. Sama halnya dengan jamaah offline, jamaah online Teras Dakwah juga mengapresiasi konten video Teras Dakwah. Video Teras Dakwah, seperti one minutes booster, web series dan super booster oleh jamaah online Teras Dakwah mendapat apresiasi. Banyak dari kalangan anak-anak muda mengenal Teras Dakwah karena konten video dakwahnya yang menarik. Seperti yang disampaikan oleh Informen, Adi Nugroho, dalam percakapan pribadi ia mengatakan:

"Saya bisa mengenal Teras Dakwah berkat dari teman saya, ketika saya ikut kajian dakwah Yuk Ngaji di sekitar Bekasi. Teman saya membagikan akun media sosial Teras Dakwah ke saya (gerakan dakwah Jogja yang kreatif, populer). Teman saya bilang video Teras Dakwah keren, kreatif-kreatif, lucu. Dari situ, kemudian saya langsung liat akun Instagram @terasdakwah. Dari awal liat unggahan kegiatan@ @terasdakwah, saya mulai langsung suka dengan Teras Dakwah karena video-videonya yang kreatif, lucu menghibur, juga ada dakwahdakwahnya, lengkap deh". ........ "Karena penasaran, saya ikut program Teras Camp. Eh di sini ketemu dengan orang-orang baru peserta Teras Camp dari berbagai daerah, asyik deh, nambah teman baru. ........yang khas dari video Teras Dakwah ialah kuluturnya yang gak bisa lepas dari budaya Jawa. Dari sini saya mulia suka, jatuh cinta dengan Teras Dakwah, sampai saya datang dari Bekasi ke sini (Teras Dakwah)." 
Dari kutipan informan penulis tersebut menunjukan bahwa salah seorang jamaah online (Adi Nugroho) asal Kota Bekasi mengenal Teras Dakwah berkat video-videonya Teras Dakwah yang diunggah melalui media sosial Teras Dakwah. Berawal dari sebuah video yang sering ia tonton, ia merasa tertarik, menyukai konten-konten video kreatif Teras Dakwah, yang akhirnya membuat ia jatuh cinta dengan Teras Dakwah membuat ia terpanggil hatinya datang ke Teras Dakwah. Hal lain juga diungkapkan oleh informen penulis (Nur Hasbullah), ia mengatakan ke saya:

"Saya kenal Teras Dakwah melalui media sosial Instagram @Shif, di saat itu juga saya melihat ada akun @ terasdakwa yang menayangkan storry IG (Instagram) Ustaz Hanan Attaki di bio media sosial @ Shif. Dari sini saya kepo dengan Teras Dakwah, kemudian saya buka, klik account-nya. Setelah saya klik muncul berbagai aktivitas kegiatan pengajian Teras Dakwah. Saya pun respon dong, saya mengatakan wah konten video ini keren. ...........tak luput dari pengelihatanku, selain tema-tema kajiannya yang menarik, videonya juga keren-keren. Dari beberapa video yang saya tonton, itu! di situ saya mulai suka dengan Teras Dakwah, videonya jadi langganan. Pada akhirnya, saat ada momen spesial, program Teras Camp, saya ikut. Saya datang jauh-jauh dari Kalimantan karena ingin ikut acara Teras Camp."

Dari kutipan pernyataan kedua informen tersebut, Mas Adi Nugroho dan Mas Abdullah tersebut, mereka mengenal Teras Dakwah berkat melalui media sosial Teras Dakwah. Mas Habullah menemukan akun Teras Dakwah berawal dari ketidaksengajaanya mengikuti storry Ustaz Hanan Attaki di media sosial @ shif, saat melihat Ustaz Hanan Attaki di storry Instagram @ shif ia melihat akun media sosial Teras Dakwah. Dari sekilas pengelihatanya tersebut, ia menelusuri akun yang telah di sebut namanya oleh Shif di bio storry @ shif. Saat melihat postingan aktivitas dakwah media sosial Teras Dakwah ia sangat terkesan, takjub dengan hasil dokumentasi-dokumentasi kajian yang dilakukan oleh Teras Dakwah. di antaranya ialah videovideo kreatif Teras Dakwah yang menginspirasi, mengedukasi, menghibur dan moral nilai-nilai dakwah.

Sedangkan Adi Nugroho mengenal Teras Dakwah dari temannya, yang merekomendasikan dirinya untuk segera mengunjungi akun media sosial Teras Dakwah. Perkenalan, menonton video kreatif Teras Dakwah, mengapresiasi, sampai datang langsung ke Teras Dakwah mengikuti Teras Camp diawali dari media sosial @ terasdakwah. Pertemuan dirinya dengan temannya saat mengikuti kajian Yuk Ngaji di Kota Bekasi, menghantarkan Adi Nugroho menjadi bagian dari jamaah online-offline Teras Dakwah. Berawal dari media sosial, Adi Nugroho dan Nur Hasbullah mengenal lebih dalam Teras Dakwah hingga akhirnya sampai di Teras Dakwah. Pada akhirnya, mereka menjadi bagian dari jamaah offfline-online Teras Dakwah.

\section{Kemampuan Teras Dakwah dalam Menayangkan Program Dakwah Tebaik}

Pendemi tidak hanya membuat masayrakat beradaptasi dengan kebiasaan baru, namun juga program ibadah seperti penyelenggaraan program pengajian yang diselenggarakan oleh berbagai lembaga keagamaan. Beradaptasi dengan kebiasan baru oleh lembaga Teras Dakwah 
ditunjukkan melalui program keagamaanya. tidak hanya menggeser dari offline ke online melainkan juga mengemas program keagamaan menjadi lebih menarik lagi, seperti desain konsep kajian, background gambar, soundsystem elektronik dan konsep desian acara. Perombakan panggung kajian juga dilakukan agar lebih fresh nuansa kajianya. Sesuatu yang baru dalam kajian akan menambah daya minat yang tinggi bagi jamaah. Bagi jamaah yang sudah lama tidak datang ke pengajian Teras Dakwah ini akan menimbulkan kerinduan. Dari kerinduan ini tumbuh rasa kecintaan jamaah ingin menikmati kembali program kajian offline Teras Dakwah, dengan harapan Covid-19 segera cepat beakhir.

Akhid Subianto selaku founder Teras Dakwah mengatakan hampir satu tahun terakhir lembaga dakwah seperti Teras Dakwah mengalami ujian yang berat. Teras Dakwah tidak bisa menyelengarakan pengajian secara offline ramai seperti biasanya. Jamaah yang datang ke Teras Dakwah dibatasi. Jika mereka ingin ikut kajian mereka harus mengikuti prosedur protokol kesehatan. Terlebih dahulu mereka harus mendaftar, mengisi data diri, riwayat sakit sebulan terakhir. Setelah itu dilakukan seleksi, bagi jamaah yang lolos seleksi baru mereka ikut. Kloter kajian akan dibagi setiap jamaah akan dibagi, di masa pendemik ini mereka boleh mengikuti kajian tiga bulan sekali. Walau terasa berat, mereka banyak yang mendaftar. Kami seleksi mereka. Kami berharap Covid-19 ini dapat segera berakhir.

Dari uraian hasil Akhid di atas menunjukkan bahwa teras dakwah sedang mengalami ini tidak hanya terjadi bagi Teras Dakwah tetapi juga semua lembaga dakwah yang mengalami masa sulit dalam beradaptasi dengan program baru. Walau terasa sulit pembatasan sosial adalah cara yang paling utama untuk pencegahan Covid-19. Namun dalam masa pendemi ini antusias jamaah ingin mengikuti kajian cukup tinggi. Hal ini terlihat dari jumlah jamaah yang mendaftarkan diri ke link Teras Dakwah. Antusias mereka yang tinggi dikarenakan rasa rindu yang mendalam. Sudah lama tidak menghadiri pengajian secara langsung membuat jamaah merasa kangen. Mereka ingin menikmati kembali sudah lama tidak menghadiri kajian secara langsung. Apalagi saat ini pembangunan gedung Teras Dakwah semakin dipercantik. Fasilitas ruangan semakin indah, terdapat ruangan baru, seperti komputer, ruang studio dakwah, ruang kantor baru dan konsep bangunan baru. Pembangunan gedung yang semakin cantik semakin membuat jamaah menginginkan cepat menikmati kajian.

\section{Teras Dakwah, Covid-19 dan Gagasan Karitasnya}

Di masa Covid-19 ini, berderma ke orang lain sangat dibutuhkan. Social distancing mengharuskan masyarakat untuk selau menjaga jarak, kemudian tetap di rumah, dan bekerja dari rumah. Beraktivitas di rumah, dan selalu bekerja di rumah untuk memutus mata rantai penyebaran virus Covid-19 di satu sisi menimbulkan berbagai persoalan, khususnya bagi masyarakat kelas bawah. Mereka akan merasa terpuruk dengan keadaan ini, sulitnya ekonomi dan pekerjaan. Bagi masyarakat miskin, Covid-19 berdampak pada hilangnya mata pencarian. Untuk mencukupi keperluan sehari-hari pun juga susah.

Di tengah situasi sulit seperti ini muncul berbagai program karitas yang digagas oleh berbagai lembaga sosial keagaman. Seperti Gerakan Teras Dakwah. Gerakan Teras Dakwah 
cukup aktif memberikan bantuan ekonomi ke masyarakat miskin. Selama bulan puasa terakhir ini, devisi TD Bergerak telah membuat program karitas yang dikhususkan untuk membantu masyarakat miskin.(Dakwah, n.d.-c).

Bagi Teras Dakwah program karitasnya diharapkan dapat meringankan beban masyarakat. Seperi dalam gambar 3. Program tersebut meliputi "Geber Pangan" (Gerak Berbagi Pangan), "Papabuah" dan bantuan alat kesehatan. Geber Pangan adalah program paket pembagian sembako. Paket sembako ini berupa beras, minyak sayur, gula, mie, roti, bumbu dapur dan sayur. Dalam satu hari, lebih dari 200 buah paket sembako terbagikan ke masyarakat miskin. Berkat kerja keras antara TD Bergerak beserta para donaturnya, gagasan program Geber Pangan tersebut dapat terbantu dengan baik. Heidi A. Campbell secara teoritis diantara komunitas offline dan online merupakan integrasi dalam masyarakat jaringan. Sebab Internet secara teori melihat lebih luas terhadap identitas komunitas, karena intraksi sosial yang terjadi di media baru sebagai alat penunjang untuk mempengaruhi dan mencerminkan hal baru di ruang lingkup sosial yang lebih luas (Campbell, 2012).

Dari program pengajian keagamaannya yang disiarkan secara online selama pendemi, Teras Dakwah terus menghimbau ke jamaah untuk berdonasi sebagian uangnnya diberikan kepada masyarakat. Masyarakat melalui nomor rekening yang telah disedikan di akun media sosialnya. Seruan untuk melakukan donasi dilakukan juga melalui pergram pengajian online. Dalam siaran live tersebut nomor rekening TD ditampilkan di layar media sosialnya. Seperti yang tertera dalam media poster kajian Teras Dakwah. Dengan demikian selain gerakan dakwah Teras Dakwah menyadarkan secara personal, Teras Dakwah juga membangun tauhid sosial sebagai program dakwahnya di tengah pandemi (Asry, 2019).

Sejumlah pantauan penulis melalui akun media sosial dan group pengurus TD, program Geber Pangan tidak hanya dinikmati masyarakat sekitarnya, tapi juga menjangkau daerah yang jauh, pelosok kota. Seperti desa Kulon Progo (Barat Jogja). Desa ini salah satu dari sekian banyak desa yang dijadikan sebagai tujuan bantuan Geber Pangan Teras Dakwah. Menurut unggahan sosial media Teras Dakwah, Daerah ini ialah daerah penghasil kerajinan tangan. Usaha sektor seni seperti ini sangat rawan yang paling terdampak atas dampak virus Covid-19. Karena daya beli masyarakat semakin menurun. Apalagi daerah Kulon Progo menurut teman-teman pengurus Teras Dakwah dijadikan sebagai salah satu tempat program Kristenisasi. Tentu, program kristenisasi yang terjadi di tempat ini menjadi fokus tujuan Teras Dakwah untuk menyalurkan bantuan karitasnya. Bantuan sembako Teras Dakwah ke Desa Kulon Progo untuk menghindari Kristenisasi warga masyarakat setempat.

Kekhawatiran atas program Kristenisasi ini yang membuat pengurus Teras Dakwah antusias untuk lebih memperhatikan masyarakat tersebut dengan harapkan agar akidahnya mereka kembali kuat. Melalui sentuhan dorongan kemanusiaan, program pangan, diharapkan hati mereka akan semakin dekat dengan Allah untuk istiqomah dalam Islam. Mengutip dari Hadist Nabi dari obrolan yang disampaikan panitia Geber Pangan, "kemiskinan adalah dekat dengan kefasikan". Perbincangan pembahasan ini kemiskinan dekat dengan kefasikan. Untuk itu pembahasan dalam Hadist ini dijadikan sebagai pijakan Teras Dakwah untuk menyelamatkan 
iman umat Islam yang lemah, sekaligus ladang berdakwah. Cara ini yang kemudian mengubah cara Teras Dakwah melalui jalan kemanusiaan dan panggilan hati.

Dakwah dengan pendekatan seperti ini lah yang kemudian lebih dibutuhkan oleh masyarakat Muslim saat ini, ketimbang hanya ceramah di hadapan masyarakat Desa Kulon Progo dalam masalah menguatkan akidah. Selain itu, ini juga akan membantu ekonomi masyarakat setempat untuk memenuhi kebutuhan sehari-hari mereka. Dengan demikian, mereka akan tersentuh hatinya. Dalam gambar tersebut diperlihatlan bagaimana masyarakat mengapresiasi pemberian sembako Teras Dakwah. Masyarakat merasa senang atas bantuan sembako tim Geber Pangan Teras Dakwah. Secara tidak langsung pendekatan ini menjadi salah satu strategi pemasaran dakwah untuk lebih mengenal Teras Dakwah.

Masyarakat kecil yang berada di pelosok kota seperti yang penulis sampaikan di atas adalah salah satu dampak pendemi Covid-19. Penghasilan dalam sektor wisata, seperti pekerja serabutan, kerajinan tangan adalah masyarakat yang merasakan langsung dampak Covid-19. Penghasilan mereka semakin buruk, pendapatan turun, kebutuhan pokok semakin meningkat. Terutama Jogja, yang sebagian besar pendapatan ekonominya ditopang dari sektor industri kreatif rumahan. Seperti merchandise dan barang-barang kerajinan.

Selain berupa pemberian sembako, Geber Pangan Teras Dakwah juga melakukan program "Nasi Box". Program ini dikususkan untuk orang-orang jalanan, pedagang kaki lima, pemulung dan Ojek Online (Ojol) Seperti berjualan koran di pinggir jalan, pedagang asongan trotoar pinggir jalan, pengemis, pemulung dan Ojol.

Sebuah vidio layanaan masyarakat Teras Dakwah pada gambar 4 ini memperlihatkan bagaimana sorang ibu-ibu sedang menangis histeris saat diberikan bantuan sembako. Ia sampaikan rasa terimaksih sedalam-dalamnya ke para anak-anak muda Geber Pangan Teras Dakwah yang sudah memberikan bantuan tersebut kepadanya. Setelah diberikan sembako, ibu tersebut kemudian diberikan nasi bungkus dan sejumlah uang. Ia begitu merasa sangat senang sekali, Seketika ibu tersebut langsung sujud di trotoar jalan. Ia berterimakasih kepada Allah yang sudah memberikan bantuan melalui panita Geber Pangan itu. Ibu tersebut mendoakan dengan penuh nada tangis bahagia tersedu-sedu kepada panitia Geber Pangan, dalam tangisannya itu, ia mengatakan: "semoga kebaikannya mas dibalas oleh Allah SWT", ungkap seorang nenek dalam gambar 3 tersebut. pada saat itu juga panita mengaminkannya.

Di momen lain, sejumlah pedagang komoditas diminta memberikan respon dampak Covid-19 bagi penjualannya, bagaimana dampak dari pendemik tersebut? Mereka menjawab: "semenjak ada Corona penghasilan pada menurun mas, sepi pengunjung, banyak para pedagang yang milih gak berjualan". Setiap siang dan malam tim Geber Pangan beraksi disejumlah jalan kota Yogyakarta untuk membagikan nasi box ke orang-orang miskin di pinggir jalan. Misalnya di Jl. Malioboro. 
Gambar 3. Program Karitas Teras Dakwah (Geper Pangan) berupa bantuan Sembako ke masyarakat kurang mampu

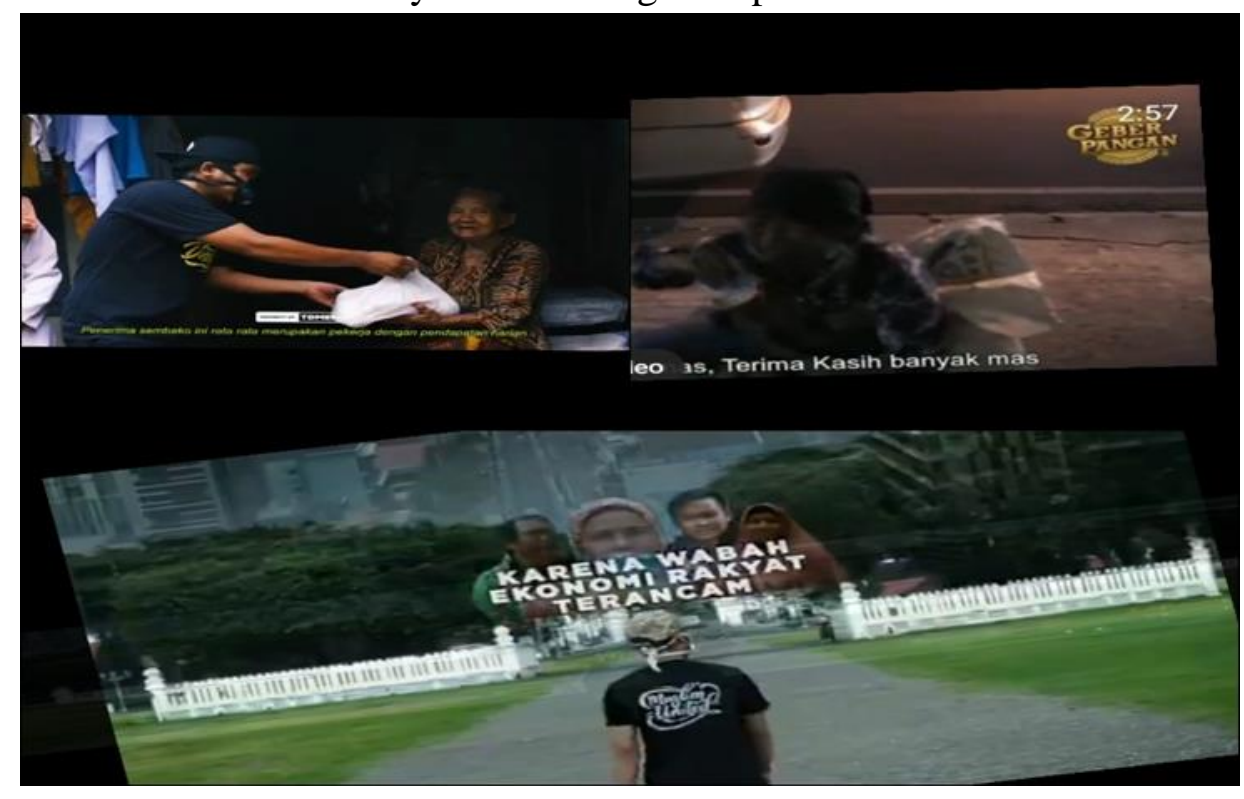

Selanjutnya, program "Papabuah". Program Papabuah juga merupakan bagian dari dampak Covid-19. Pogram karitas Papabuah secara khusus ditujukan untuk anak-anak yang membutuhkan gizi. Lesunya ekonomi selama pendemi membuat penghasilan kepala keluarga semakin merosot, ayah tidak bisa memberikan asupan gizi yang cukup untuk anaknya, sehingga menyebabkan rentan ketahanan kesehatan anak.

Dari sharing ketahanan gizi di masa pandemi program dakwah Ruang Tamu Podcast Teras Dakwah, seorang narasumber mengatakan bahwa sulitnya mencari uang di masa Covid-19 menyebabkan keluarga rentan terhadap pernyakit. Sedangkan menjaga kesimbangan tubuh sangat dibutuhkan di saat kondisi Covid-19 ini. Kebutuhan asupan nutrisi yang tidak cukup pada anak berdampak pada ganggu kesehatan dan pertumbuhan. Oleh sebab itu, kehadiran program Papabuah dapat membantu seorang kepala keluarga dalam memberikan kebutuhan nutrisi yang cukup pada anak. Program seperti ini sangat baik dalam menyentuh hati masyarakat yang membuat Teras Dakwah semakin berkesan di mata masyarakat miskin. Sehingga dengan upaya dakwah yang dilakukan Teras Dakwah secara maksimal mampu mengubah masyarakat menjadi lebih baik atau an-nur (Hasan, 2015).

Selain memberikan bentuk sembako, makanan, dan program Papabuah, TD Bergerak juga mengkampanyekan pola hidup sehat. Untuk mencegah penyebaran Covid-19, sesuai ajuran pemerintah, TD Bergerak melakukan protokoler pencegahan dan keselamatan Covid-19. Di antaranya: pertama social distancing (jaga jarak). Pembatasan sosial atau Jaga jarak dilakukan melalui pembatasan jamaah dengan cara tidak menyelenggarakan pengajian secara offline. Program pengajian offline seluruhnya dialihkan ke media daring, berupa Instagram, Youtube dan Fanspage. Selama pendemi belum berakhir, ngaji rutinitas jamaah masih tetap dilakukan di media sosial Teras Dakwah sampai wabah Covid-19 benar-benar berakhir. Sedangkan untuk 
pengurus, social distancing juga diberlakukan pembatasan kunjungan ke Teras Dakwah. Mereka tidak diperbolehkan datang ke Teras Dakwah, hanya pengurus-pengurus tertentu yang dapat diperbolehkan datang ke Teras Dakwah. Hal ini dilakukan semata-mata untuk penanganan pencegahan, memotong mata rantai penyebaran virus Covid-19.

Gambar 4. Program Papabuah dicituskan dari dampak pendemi

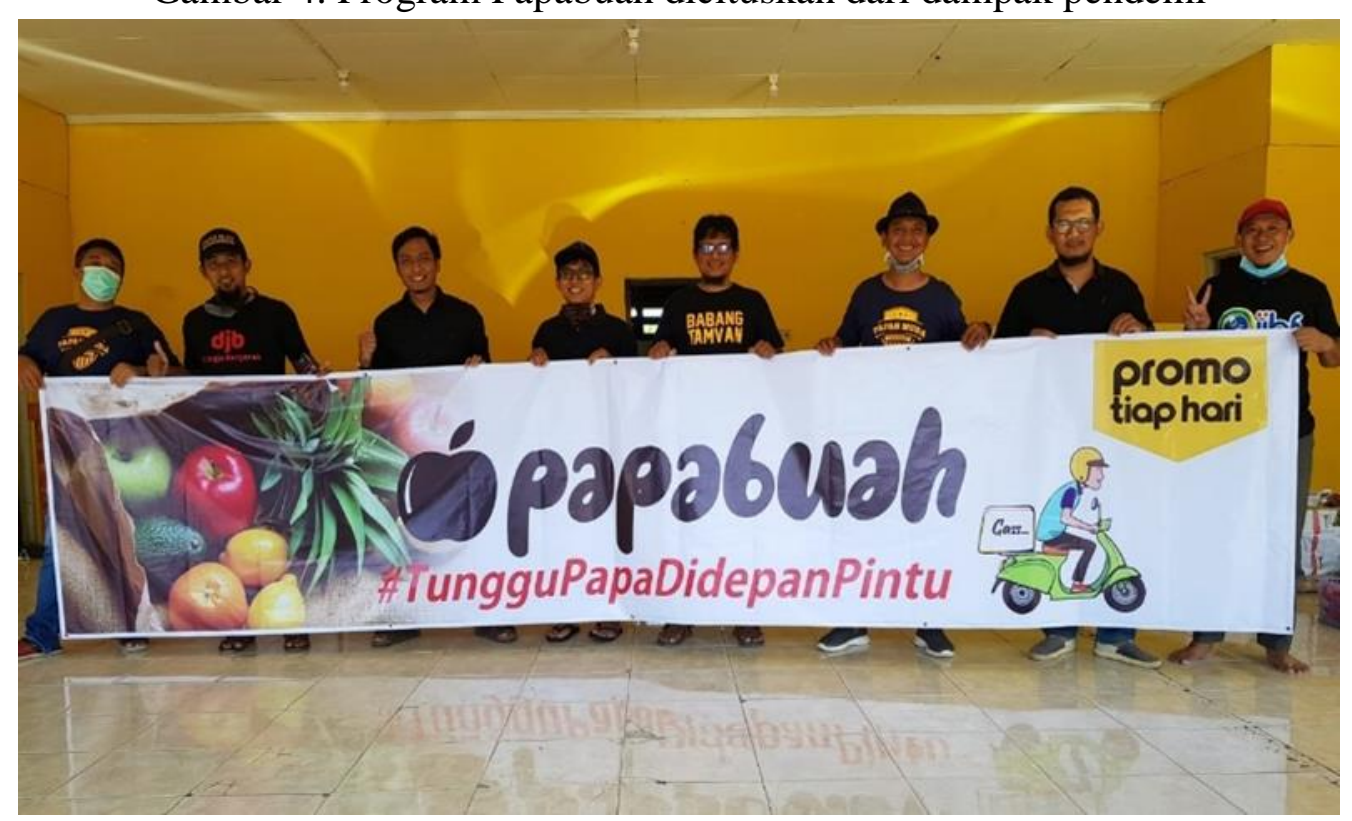

Selanjutnya pembatasan social distancing dipromosikan melalui media sosial poster Teras Dakwah, seperti IG story, Tema Kajian dan TD Nasehat. Kemudian himbauan dalam bentuk ceramah yang disampaikan melalui pengajian online, dan beberapa bentuk video iklan layanan masyarakat. Video tersebut tertera dalam gambar 4. Jika disimak video tersebut edukatif, selain itu videonya juga lucu, kreatif, dan menghibur. Mengemas penanganan Covid-19 dalam konten dakwah yang lucu membuat netizen merasa terhibur. Dengan begitu, video tersebut memudahkan masyarakat untuk mengingat akan bahayanya Covid-19.

Berdasarkan komentar para netizen di media sosial Teras Dakwah, mereka sangat menyukai video PSBB yang diperankan oleh ketiga penokohan orang tersebut. Penokohan yang diperankan oleh ketiga orang tersebut mengubah persepsi para netizen yang lebih berhati-hati akan bahayanya Covid-19. Bahasa yang disampaikan juga ringan lebih ringan dari protokol gugus tugas Covid-19 Istana Kepresidenan, dan mudah dipahami oleh netizen, bahkan sekalipun itu anak-anak dan orang awam sekalipun.

Vidio social distancing telah ditonton sebanyak 4418 kali, 64 komentar. Beberapa komentar netizen, mereka mengatakan video tersebut "mantul, keren abiz, saya cinta TD". Ketiga orang tokoh pemeran karakter video Social Distancing ini mengundang antusias yang tinggi jamaah online dan juga tawa. Karena isi konten yang 'humor' (lucu). Melalui komentar di kolom unggahan Social Distancing tersebut jamah terhibur dengan penampilan aksi ketiga orang tersebut, seperti laki-laki yang memakai seragam oranye, jamaah dibuat 'terpingkal-pingkal'. Yang tak kalah menarik dari video tersebut adalah liriknya yang lucu. Musik yang dijadikan 
sebagai background soundcraft video tersebut diambil dari musik anak-anak. Para netizen banyak yang mengatakan musiknya tersebut gemesin, lucu, gokil. Ditambah dengan pemeran bintang Social Distancing tersebut yang lucu, imut-imut, semakin menambah suasana mencair. Lagu tersebut mengadopsi dari Tasya Slay One 7 yang dimodifikasi dalam genre komedi. Melalui layanan ini jamaah tidak hanya semakin membuat masyarakat sadar, betapa pentingnya untuk menjaga jarak (social distancing), namun juga sebagai bentuk hiburan masyarakat di saat pendemi sekarang ini.

Di antara pesan video poster tersebut masyarakat Muslim untuk tidak melakukan tradisi salaman, hal ini akan semakin mempercepat penyebaran virus Covid-19. Dengan tidak melakukan salaman, ini akan semakin cepat memutus mata rantai penyebaran Covid-19. Dalam situasi seperti ini, ustaz Feri Septianto, seorang ustaz muda Teras Dakwah, ia membolehkan untuk sementara tidak bersalaman. Karena hal ini akan lebih banyak berdampak pada cepat menularnya virus Covid-19. Selanjutnya seat at home (tetap di rumah), work for home (kerja di rumah), dan ngaji for home (ngaji di rumah). Ketiga hal ini ajuran untuk beraktivitas di dalam rumah. Melalui media sosialnya, Intagram dan Telegram, ketiga anjuran untuk berkativitas di dalam rumah dikampanyekan melalui media sosial. Dari video poster tersebut banyak jamah mengapresiasi langkah Teras Dakwah dalam pencegahan Covid-19.

Selain mengkampanyekan pencegahan Covid-19 melalui PSBB, Teras Dakwah juga mengajak para jamaah pengajiannya untuk melalukan donasi. Bedonasi untuk membantu sausara-saudara Muslim yang terdampak atas kesulitan ekonomi di masa pendemik ini. Terutama bagi masyarakat kecil yang mata pencariannya diperoleh dari kerja harian. Seperti buruh harian, nenek-nenek tua renta, pengontel becak dan pemulung. Anjuran untuk berdonasi ke nomor rekening yang sudah ditunjuk disosialisasikan melalui media sosialnya dalam bentuk media poster kajian dan video poster iklan kajian. Selain itu anjuran untuk berdonasi juga diserukan oleh ustaz-ustaz TD dalam ceramah pengajian online-nya. Seperti Ngaji Teras, Ngaji Anida. Kemudian dengan adanya pandemi ini dakwah saat ini semakin sulit, karena persoalan kehidupan bertambah pelik, rumit dan komplek (Munfaridah, 2013). Namun, diharapkan dengan kolaborasi pendekatan dakwah struktural dan cultural, dakwah yang dilakukan oleh gerakan Teras Dakwah dapat menyentuh seluruh lapisan masyarakat yang memiliki berbagai karakteristik dan lingkungan komunitas yang heterogen dalam mencegah serta memutus mata rantai penyebaran Covid-19 (Bachtiar, 2013).

\section{Kesimpulan}

Wabah Covid-19 yang melanda dunia khususnya di Indonesia mendorong lajunya perubahan sosial dan praktik keagamaan di masyarakat. Hal ini kemudian berdampak pada praktik keagamaan masyarakat Indonesia khususnya agama Islam yang menjalankan aktivitas keagamaan, seperti ritual keagamaan, program-program keagamaan, pengajian-pengajian dan lainnya. Covid-19 membuat lembaga dakwah mengalami perubahan, sehingga mempengaruhi penyelenggaraan ibadah. Covid-19 juga mengubah tradisi umat Islam yang mana biasanya umat Islam melakukan praktik keagamaan di tempat-tempat ibadah, melakukan kajian keagamaan 
berjamaah, namun karena terjadinya pendemi Covid-19 mereka harus menjalankan semua aktivitas ibadah di rumah. Teras Dakwah (TD) hadir sebagai lembaga yang berusaha menjawab persoalan yang terjadi di tengah-tengah pandemi Covid-19. Teras Dakwah menghimbau kepada jamaahnya untuk selalu menerapkan protokol kesehatan (5M) yaitu mencuci tangan, memakai masker, menjaga jarak, membatasi mobilitas, menjauhi kerumunan. Dengan demikian jamaah dapat memutus mata rantai penularan dan penyebaran pandemi Covid-19. Berbagai program Teras Dakwah (TD) di antaranya yaitu menyajikan pesan dakwah melalui media sosial dalam menyiarkan ajaran Islam, selain itu juga untuk membuat masyarakat supaya tidak jenuh menjalani kehidupan dimasa pandemi ini sehingga selalu mematuhi protokol kesehatan dan tetap di rumah. Kemudian, selain menyampaikan pesan dakwah melalui program yang di-share di media sosial, Teras Dakwah (TD) juga melakukan aksi ke lapangan memberikan bantuan sosial berupa sembako kepada masyarakat yang kurang mampu, memberikan nasi kotak kepada pemulung, ojek online, untuk memenuhi kebutuhan sehari-hari mereka. Dengan program yang dilakukan oleh Teras Dakwah ditujukan supaya masyarakat tetap di rumah, menghindari kerumunan sehingga dapat memutuskan mata rantai penularan dan penyebaran virus Covid-19, dengan demikian berharap kedepannya pandemi Covid-19 segera berakhir dan bisa melakukan aktivitas normal seperti biasa.

\section{Referensi}

Alkaf., M. (2020). Agama, Sains, dan Covid-19: Perspektif Sosial-Agama. Jurnal Maarif, 15(1). Amran, A. (2015). peranan agama dalam perubahan sosial masyarakat. Hikmah, 2(1), 23-39.

Asry, N. (2019). Model Gerakan Dakwah di Indonesia. Al-Din Jurnal Dakwah Dan Sosial Keagamaan, 4(1).

Bachtiar, M. A. (2013). Dakwah Kolaboratif: Model Alternatif Komunikasi Islam Kontemporer. Jurnal Komunikasi Islam, 3(1).

Buana, D. R. (2020). Analisis Perilaku Masyarakat Indonesia dalam Menghadapi Pandemi Virus Corona (Covid-19) dan Kiat Menjaga Kesejahteraan Jiwa. Jurnal Sosial Dan Budaya Syar'i, 7(3).

Campbell, H. A. (2012). Digital Religion: Understanding Religious Practice in New Media Worlds (Routledge (ed.)

Castell, M. (2000). Materials for an Exploratory Theory of Network Society. British Journal of Sociology, 51(1).

D, M. A. (2012). Revitalisasi Peran Masjid Sebagai Basis Dan Media Dakwah Kontemporer. Jurnal Dakwah Tabligh, 13(1).

Dakwah, T. (n.d.-a). Read Caption. Www.Insragram.Com. Retrieved February 24, 2021, from https://www.insragram.com/tv/B9_wMnlFfmh/?igshid=13rk7d6o5z4na

Dakwah, T. (n.d.-b). Superbooster Ramadhan \#29 Menembus Penghalang, Menjemput Jodoh Impian. Www.Insragram.Com. Retrieved March 19, 2021, from https://www.instagram.com/p/B_7kxaalECV/?igshid=1k277zcjiq08t 
Dakwah, T. (n.d.-c). Terancam! Retrieved February 25, 2021, from https://www.instagram.com/p/CACnPaXFJin/?igshid=1ifn7xft3n1jk.

Hasan, J. (2015). Perubahan Sosial Dalam Perspektif Dakwah. Jurnal Al-Bayan, 21(2).

M., M. (2020). Covid-19, Agama, dan Sains. Jurnal Maarif, 15(1).

Mughni, S. A. (2011). Di Balik Simbol: Memahami Pesan Agama dengan Semangat Kemajuan. Hikmah Press.

Munfaridah, T. (2013). Strategi Pengembangan Dakwah Kontemporer. Jurnal Kajian Dan Keislaman, 2(2).

Nurdiana, T. (n.d.). Indonesia Catat Kasus Corona Tertinggi di Asia Tenggara, nomer 4 di Asia, no 19 dunia. Www.Kontan.Co.Id. Retrieved February 24, 2021, from https://kesehatan.kontan.co.id/news/indonesia-catat-corona-tertinggi-di-asia-tenggaranomer-4-di-asia-no-19-dunia,di Kontan.co.id.

Saputra, E. (2020). Teras Dakwah, Agama Pasar: Lanskap dan Pergeseran Gerakan Dakwah di Indonesia. Jurnal Idarotuna Kajian Manajemen Dakwah, 3(1).

Sari, H. P. (n.d.). 1.298.608 Kasus Covid-19 di Indonesia dan Angka Kematian yang Tak Bisa Ditoleransi. Www.Kompas.Com. Retrieved February 27, 2021, from https://nasional.kompas.com/read/2021/02/24/06185551/1298608-kasus-covid-19-diindonesia-dan-angka-kematian

Sholeh, K. A. N. (n.d.). Fatwa No 14 Tahun 2020 - Penyelenggaraan Ibadah dalam Situasi Terjadi Wabah Covid-19. Majelis Ulama Indonesia. Retrieved February 24, 2021, from https://mui.or.id/berita/27674/fatwa-penyelenggara-ibadah-dalam-situasi-terjadi-wabahcovid-19/ di mui.or.id.

Siahaan, H. E. R. (2017). Aktualisasi Pelayanan Karunia Di Era Digital. EPIGRAPHE: Jurnal Teologi Dan Pelayanan Kristiani, 1(1).

Toresano, W. O. Z. Z. (2020). Itegrasi Sains Dan Agama: Meruntuhkan Arogansi Di Masa Pandemi Covid-19. Jurnal Maarif, 15(1).

Triantoro, D. A. (2018). Dakwah dan Kesalehan: Studi Tentang Gerakan Teras Dakwah di Kota Yogyakarta. Jurnal Masyarakat Dan Budaya, 20(2), 273-286. https://doi.org/10.14203/jmb.v20i2.624

Triantoro, D.A, Saputra, E \& Wahyuni, T. (2019). Mengelola Hibridasi Identitas Anak Muda Islam: Studi Pada Lembaga Teras Dakwah Di Yogyakarta. Jurnal Manajemen Dakwah, 5(2), 113-139. https://doi.org/10.14421/jmd.2019.52-01

Zaenuri, A. (2020). Konsepsi Fikih Dakwah Jama'ah Tabligh Pada Masa Pandemi Covid-19: Telaah Gerakan Dakwah Jama'ah Tabligh Gorontalo. Jurnal of Islamic Law, 1(2).

Zaprulkhan. (2015). Filsafat Ilmu: Sebuah Analisis Kontemporer. Rajawali Press. 